\title{
Penerapan Algoritma Crawling dalam Otomatisasi Verifikasi Pembayaran Tiket Seminar
}

\author{
Eldy Dwi Sentosa*, Iskandar Fitri, Agus Iskandar \\ Fakultas Teknologi Komunikasi Dan Informatika, Universitas Nasional, Jakarta Selatan, Indonesia \\ Email: 1,*eldydwi15@gmail.com, ${ }^{2}$ tektel2001@yahoo.com, ${ }^{3}$ agus.iskandar@civitas.unas.ac.id \\ Email Penulis Korespondensi: eldydwi15@gmail.com
}

\begin{abstract}
Abstrak- Sistem untuk melihat data pembayaran seminar mahasiswa dapat dilihat melalui kontrol admin. Proses verifikasi pembayaran seminar mahasiswa Universitas Nasional masih menggunakan sistem manual dengan membayar kepada penyelenggara seminar sehingga membutuhkan waktu yang lebih lama untuk proses pembayaran seminar. Tujuan di buatnya system ini adalah untuk mempercepat waktu dalam pembayaran seminar. Sistem ini memanfaatkan 3 digit kode unik di setiap pembayaran peserta seminar, 3 digit kode unik ini berperan sebagai tanda pembeda pada pembayaran mahasiswa supaya tidak memerlukan konfirmasi ke penyelenggara seminar. Cron job akan diimplementasi pada system operasi berbasi UNIX (Linux, Ubuntu, dan lain-lain) yang berfungsi untuk menjalankan task atau script secara otomatis. Isi dari script adalah perintah untuk menjalankan perintah verifikasi pembayaran terhadap peserta. Tahap penelitian ini terdiri dari beberapa tahap yaitu analisis kebutuhan, desain, penulisan kode aplikasi sistem, pengujian aplikasi. Penelitian menghasilkan aplikasi yang dapat mempercepat proses verifikasi pembayaran dengan cara mencocokan jumlah transfer peserta dengan yang ada pada database. Hasil pengujian proses verifikasi pembayaran di pengaruhi oleh Algoritma Crawling membantu proses pembayaran agar lebih efektif. Dengan hasil yang sudah di uji rata rata menunjukkan waktu 4.8s untuk melakukan verifikasi terhadap pembayaran peserta. Dengan adanya sistem pembayaran seminar ini, dapat menghemat waktu untuk melakukan proses pembayaran seminar.
\end{abstract}

Kata Kunci: Sistem Pembayaran Otomatis; Algoritma Crawling; Website; OVO; GoPay; Bank BCA

Abstract-The system for viewing student seminar payment data can be viewed through administrator controls. The seminar payment confirmation process for National University students still uses the manual system by paying the seminar organizer so it takes longer to process the seminar payment. The purpose of creating this system is to speed up the payment time of the seminar. This system uses a unique 3-digit code in each payment of seminar participants, this unique 3-digit code acts as a mark that differentiates student payments so that it does not require confirmation to the seminar organizer. Cron work will be performed on UNIX-based operating systems (Linux, Ubuntu, etc.) which function to perform tasks or scripts automatically. The content of the script is an order to execute the payment confirmation order against the participant. This level of research consists of several stages, namely needs analysis, design, writing system application code, application testing. This investigation has resulted in an application that can expedite the payment verification process by matching the number of transfer participants with those in the database. The results of testing the payment verification process are influenced by the Crawl Algorithm to help the payment process become more effective. With results that have been tested on average, it shows 4.8 seconds to confirm the participant's payment. With this seminar payment system, you can save time to process seminar payments.

Keywords: Automatic Payment System; Crawl Algorithm; Website; OVO; GoPay; BCA Bank

\section{PENDAHULUAN}

Perkembangan teknologi informasi di Era sekarang ini sangat pesat. Dengan kemajuan teknologi informasi, mengakses data atau informasi dapat berlangsung dengan cepat dan akurat. Terlebih khusus pada sistem proses verifikasi pembayaran sebelumnya dikerjakan secara manual. Teknologi otomasi merupakan perintah pemrograman secara logika dan mekanisme untuk menggantikan pengambilan keputusan maupun perintah manual dengan kata lain proses transfer kemampuan untuk mengontrol maupun mengoperasikan sesuatu dari manual ke otomatis.

Seminar adalah suatu pertemuan sekelompok orang dengan tujuan untuk membahas suatu topik yang sudah ditentukan dan mencari solusi permasalahan dengan cara tanya - jawab. Di kampus Universitas Nasional Jakarta ini sistem proses pembayaran seminarnya masih dilakukan dengan cara manual. Hal ini tentu kurang efektif sehingga akan membutuhkan waktu yang lama untuk memproses pembayaran peserta seminar.

Dengan menggunakan 3 digit kode unik di setiap pembayaran peserta seminar akan mempercepat proses verifikasi pembayaran seminar. Proses verifikasi pembayaran akan berjalan sesuai dengan jadwal yang telah di buat pada Cron sehingga penyelenggara tidak perlu melakukan verifikasi pembayaran dengan cara manual.

Pada penelitian terdahulu dilakukan penelitian yang berjudul Keamanan Sistem Transaksi Dan Pembayaran Pada E-Commerce, dimana aplikasi sistem pembayaran dengan keamanan pembayaran yang membutuhkan bukti untuk menjamin kepercayaan[1].

Penelitian terkait juga dilakukan pada penelitian yang berjudul Perancangan Sistem Pembayaran Non Tunai, dimana aplikasi pembayaran non -tunai ini dapat mempercepat pada saat transaksi karena media pembayaran bukan dengan uang tunai melainkan uang digital [2]. Penelitian serupa juga dilakukan pada penelitian yang berjudul Implementasi Sistem Informasi Pembayaran SPP Berbasis Web, Barcode dan SMS Gateway, dimana aplikasi ini dapat mempermudah pekerjaan sehingga pengelolaan pembayaran SPP dapat berjalan dengan tepat dan akurat [3]. Penelitian terkait hal berikut juga dilakukan pada penelitian yang berjudul Perancangan Sistem 
Informasi Pembayaran Spp Berbasis Web Pada Yayasan Pendidikan Dewi Kunti, dimana aplikasi ini dapat mengelola data pembayaran SPP maupun data siswa secara cepat dan tepat [4]. Penelitian serupa juga dilakukan pada penelitian yang berjudul Sistem Informasi Billing pada Rumah Sakit Jiwa Berbasis Web, dimana aplikasi ini dapat diterapkan pada proses pendaftaran, pemeriksaan dan pembayaran di Rumah sakit Dr. Soeharto Heerdjan [5]. Penelitian terkait juga dilakukan pada penelitian yang berjudul Perancangan Aplikasi Smart Seminar Dan Workshop Berbasis Website, dimana aplikasi ini dapat diterapkan untuk membantu penyelenggaraan pada seminar dan workshop [6]. Penelitian serupa juga dilakukan pada penlitian yang berjudul Rancang Bangun Sistem Informasi Kegiatan Seminar Nasional Berbasis Web Pada Institut Informatics Dan Bisnis Darmajaya, dimana aplikasi ini dapat diterapkan untuk informasi website yang dapat menangani pendaftaran peserta seminar nasional berbasis web [7]. Penelitian ini juga dilakukan pada penelitian yang berjudul Perancangan Sistem Informasi Pendaftaran Seminar Mahasiswa Pascasarjana Institut Pertanian Bogor, dimana aplikasi ini dapat membantu pendaftaran seminar untuk mahasiswa Institut Pertanian Bogor [8]. Penelitian terkait juga dilakukan pada penelitian yang berjudul Perancangan Dan Pembangunan Sistem Informasi Portal Seminar Dan Jurnal Berbasis Web Menggunakan Framework Codeigniter, dimana aplikasi ini dapat membantu memberikan informasi mengenai seminar yang berguna bagi dosen. Informasi yang diberikan adalah nama seminar [9]. Penelitian serupa juda dilakukan pada penelitian yang berjudul Aplikasi Pendaftaran Seminar Menggunakan Metode Mvc Berbasis Website Menggunakan Framework Codeigniter 3.1.10, dimana aplikasi ini dapat membantu membantu dan mempermudah pengguna dalam mendapatkan informasi tentang seminar dan juga dalam melakukan pendaftaran seminar lalu dapat mencetak sertifikat secara langsung [10]. Penelitian serupa juga dilakukan dengan penelitian Pengembangan Sistem Informasi Seminar dan Skripsi Mahasiswa, dimana aplikasi ini dapat berfungsi sebagai sarana pendataan, monitoring, dan evaluasi skripsi mahasiswa IKIP PGRI Pontianak [11].

Untuk membatasi permasalahan agar tidak menimbulkan kekeliruan serta meluasnya permasalahan, maka tujuan ini dapat mempercepat proses verifikasi pembayaran.

Tujuan dari penelitian ini yaitu untuk mempercepat proses verifikasi pembayaran seminar yang ada pada kampus Universitas Nasional.

\section{METODOLOGI PENELITIAN}

Metode Perancangan yang digunakan dalam penelitian ini meliputi metode pembayaran, sistem keamanan website, perancangan sistem, dan penerapan Algoritma Crawling.

\subsection{Metode Pembayaran}

Metode Pembayaran yang dilakukan pada transaksi ini menggunakan BANK BCA, OVO, dan GOPAY menggunakan 3 digit kode unik yang berfungsi sebagai tanda pembeda pada setiap pembayaran peserta seminar.

\subsection{Perancangan Sistem}

Tahap perancangan sistem ini terdiri dari:

1) Analisis Kebutuhan

Pada tahap ini terdiri dari mengumpulkan informasi dan menganalisa kebutuhan sistem yang akan dikerjakan. Proses pengumpulan data dalam pembangunan system ini dilakukan dengan cara observasi dan melakukan wawancara kepada narasumber yang pernah mengikuti sebuah acara seminar [12].

\section{A. Analisis Kebutuhan Perangkat Keras}

Perangkat keras yang digunakan adalah laptop. Laptop tersebut digunakan untuk mengoperasikan sistem pembayaran otomatis tiket seminar.

B. Analisis Kebutuhan Perangkat Lunak

Perangkat lunak yang digunakan adalah Control Panel sebagai server localhost dimana sistem dan database disimpan, browser digunakan untuk menampilkan halaman sistem, dan Visual Studio Code digunakan untuk penulisan coding untuk sistem yang akan di buat.

\section{2) Desain}

Pada tahap ini membuat desain yang sudah ditentukan ditahap analisa atau tahap pertama.Desain tersebut antara lain DFD (Data Flow Diagram), dan Rancangan Antar Muka pengguna dari Sistem.

\section{3) Perancangan Sistem Aplikasi}

Perancangan ini akan menjelaskan tentang cara kerja sistem, dan pembuatan desain UI untuk digunakan pada aplikasi. Developer diberikan akses untuk mendaftarkan, mengubah, dan menghapus data Admin, melihat seminar yang didaftarkan Admin, dan melihat semua peserta seminar. Akses yang diberikan kepada Admin untuk menambahkan, mengubah, dan menghapus seminar. Admin juga dapat mengubah dan menghapus peserta seminar, serta Admin bisa menambahkan, mengubah, dan menghapus rekening pembayaran. Dan Admin juga diberikan akses untuk export data peserta seminar yang sudah melakukan pembayaran.

4) Pengujian Aplikasi 
ISSN 2614-5278 (media cetak), ISSN 2548-8368 (media online)

Available Online at https://ejurnal.stmik-budidarma.ac.id/index.php/mib DOI 10.30865/mib.v5i1.2578

Pada tahap ini pengujian bertujuan untuk mengetahui apakah fitur-fitur yang terdapat pada sistem pembayaran otomatis seminar ini dapaat berjalan sesuai dengan rencana. Metode yang digunakan adalah metode blackbox.

\section{HASIL DAN PEMBAHASAN}

\subsection{Penerapan Algoritma}

Web crawler adalah bagian komponen yang ada pada search engine. Web crawler memiliki fungsi dalam pengambilan informasi dari halaman web yang terdapat di internet. Hasil pengumpulan situs web akan di indeks untuk mempermudah dalam pencarian informasi. Proses secara singkat pada web crawler adalah memberikan URL awal sebagai penelusuran dalam sebuah antrian. Kemudian crawler akan mendownload dan menyimpan halaman website kedalam koleksi halaman website yang akan diurai untuk diekstrak ke outgoing link yang belum di kunjungi dan kembali dimasukkan kedalam antrian. Proses itu akan terus berlangsung sampai antrian dari URL terpenuhi [13][14][15]. Penerapan Algoritma Crawling pada aplikasi verifikasi pembayaran dapat dilihat pada flowchart dibawah ini.

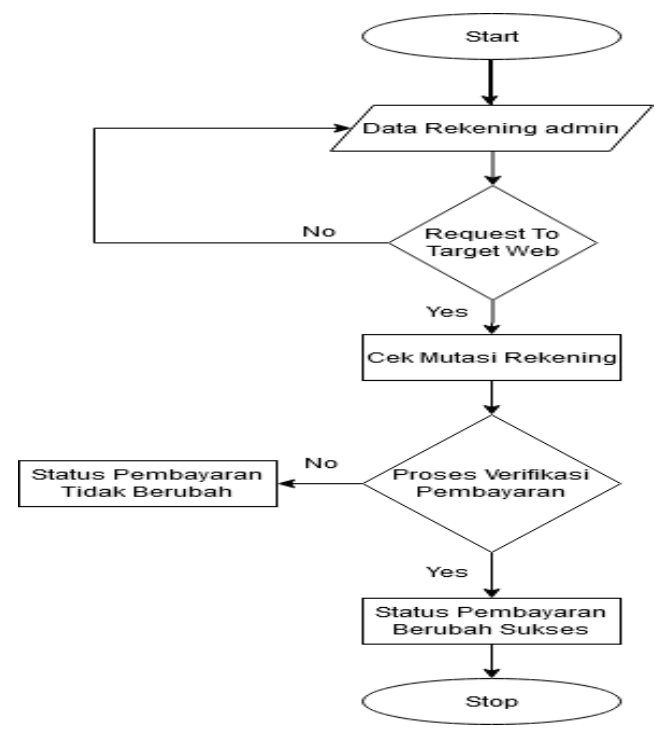

Gambar 1 Implementasi Algoritma Crawling pada aplikasi

Hasil pada algoritma crawling digunakan untuk verifikasi proses pembayaran. Semakin banyak pembayaran maka akan semakin menurun kecepatan proses verifikasi pembayaran. Use Case Diagram perancangan aplikasi ini terdapat 2 aktor yaitu Developer dan Admin. Setiap aktor diharuskan login sebelum menggunakan sistem. Use Case Diagram perancangan aplikasi ini dapat dilihat pada gambar 2

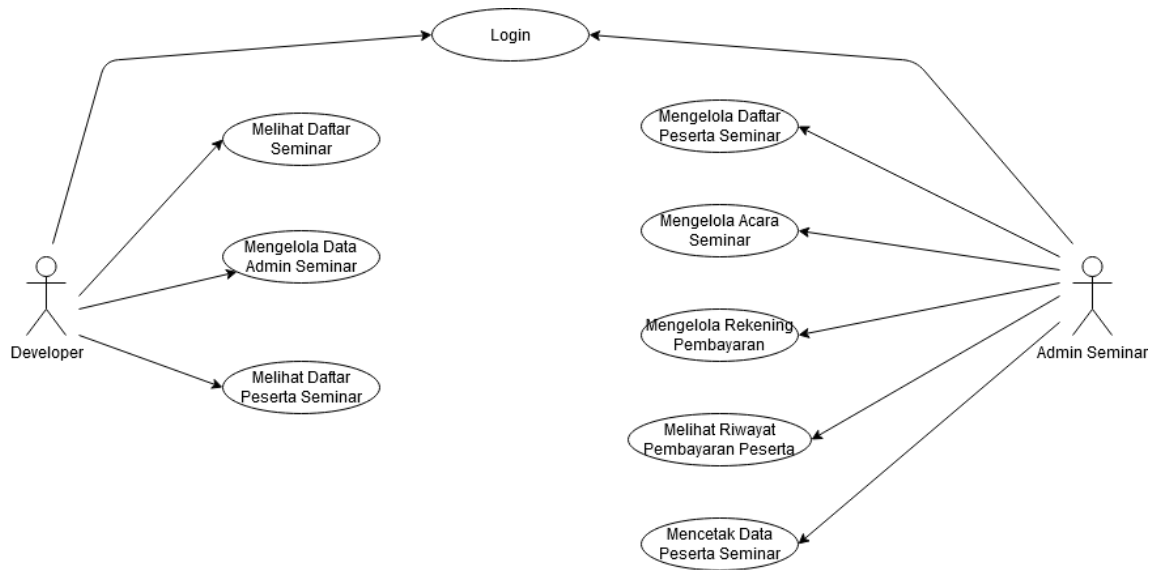

Gambar 2 Use Case Diagram

\subsection{Implementasi User Interface (UI)}

\section{a. Halaman Dashboard Developer}

Halaman Dashboard Developer adalah halaman awal yang tertampil ketika developer melakukan login ke dalam sistem. Pada dashboard developer, terdapat menu Konfigurasi Website, Admin Seminar, Peserta Seminar, Daftar Seminar. Tampilan halaman dashboard developer dapat dilihat pada Gambar 3. 
JURNAL MEDIA INFORMATIKA BUDIDARMA

Volume 5, Nomor 1, Januari 2021, Page 129-137

ISSN 2614-5278 (media cetak), ISSN 2548-8368 (media online)

Available Online at https://ejurnal.stmik-budidarma.ac.id/index.php/mib

DOI 10.30865/mib.v5i1.2578

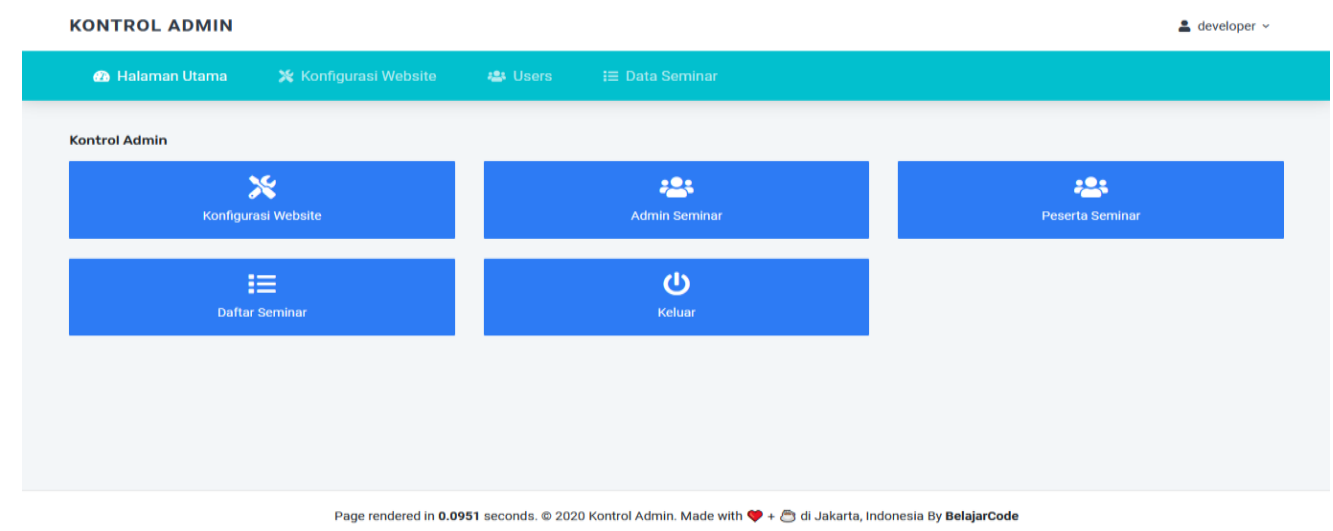

Gambar 3. Tampilan Dashboard Developer

\section{b. Halaman Konfigurasi Website}

Halaman Konfigurasi Website adalah halaman yang digunakan mengatur title, deskripsi, logo, keyword, dan status maintance halaman user. Tampilan halaman Konfigurasi Website dapat dilihat pada Gambar 4.

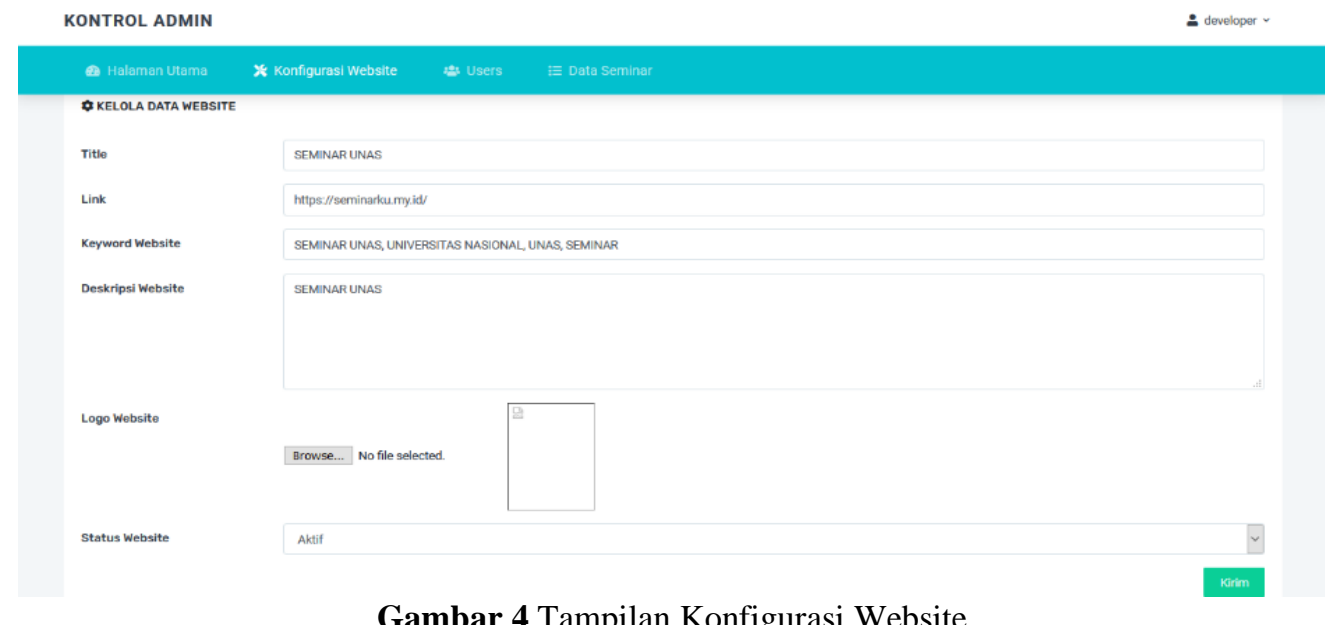

\section{c. Halaman Daftar Admin}

Halaman Daftar Admin adalah halaman dimana developer mendaftarkan akun admin, dengan mengisi username, fakultas, dan password untuk admin login kedalam sistem. Tampilan dapat dilihat pada Gambar 5.

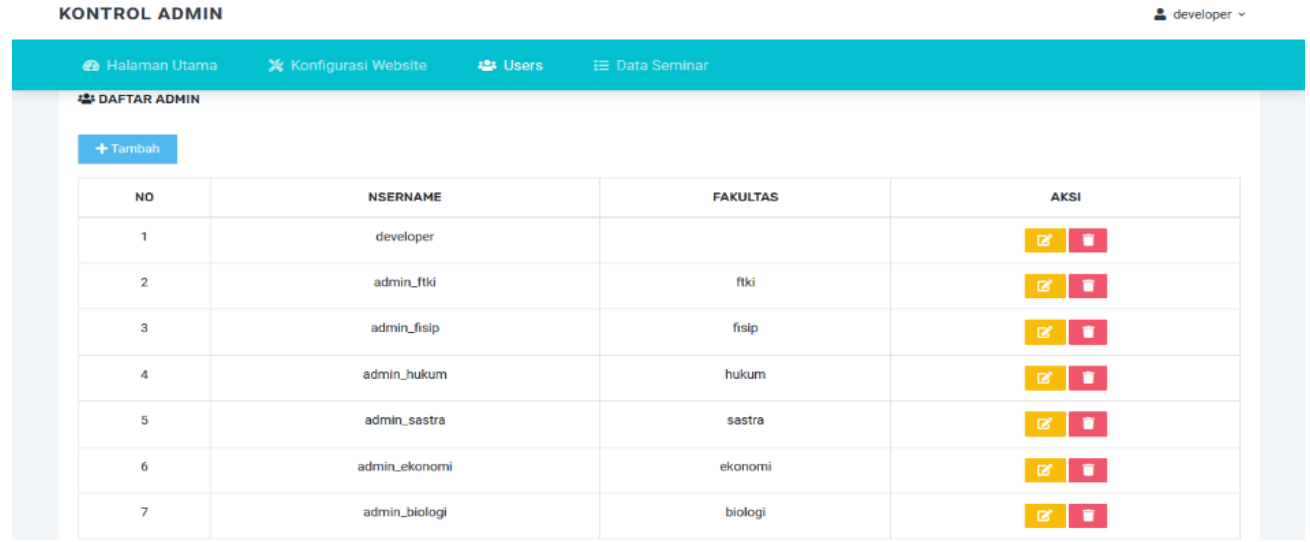

Gambar 5. Tampilan Daftar Admin

\section{d. Halaman Daftar Peserta Seminar}

Halaman Daftar Peserta Seminar adalah halaman dimana developer dapat melihat peserta seminar yang sudah didaftarkan admin. Tampilan halaman Daftar peserta seminar dapat dilihat pada Gambar 6 
JURNAL MEDIA INFORMATIKA BUDIDARMA

Volume 5, Nomor 1, Januari 2021, Page 129-137

ISSN 2614-5278 (media cetak), ISSN 2548-8368 (media online)

Available Online at https://ejurnal.stmik-budidarma.ac.id/index.php/mib

DOI 10.30865/mib.v5i1.2578

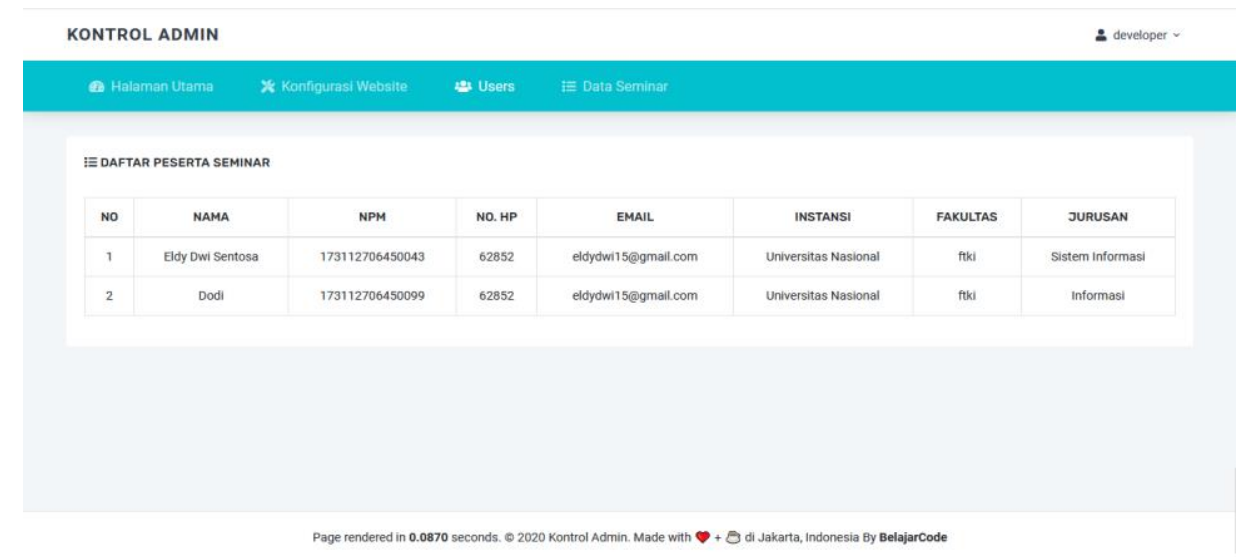

Gambar 6. Tampilan Daftar Peserta Seminar

\section{e. Halaman Daftar Seminar}

Halaman Daftar Seminar adalah halaman dimana developer melihat semua daftar seminar yang di daftarkan admin. Tampilan halaman daftar seminar dapat dilihat pada Gambar 7.

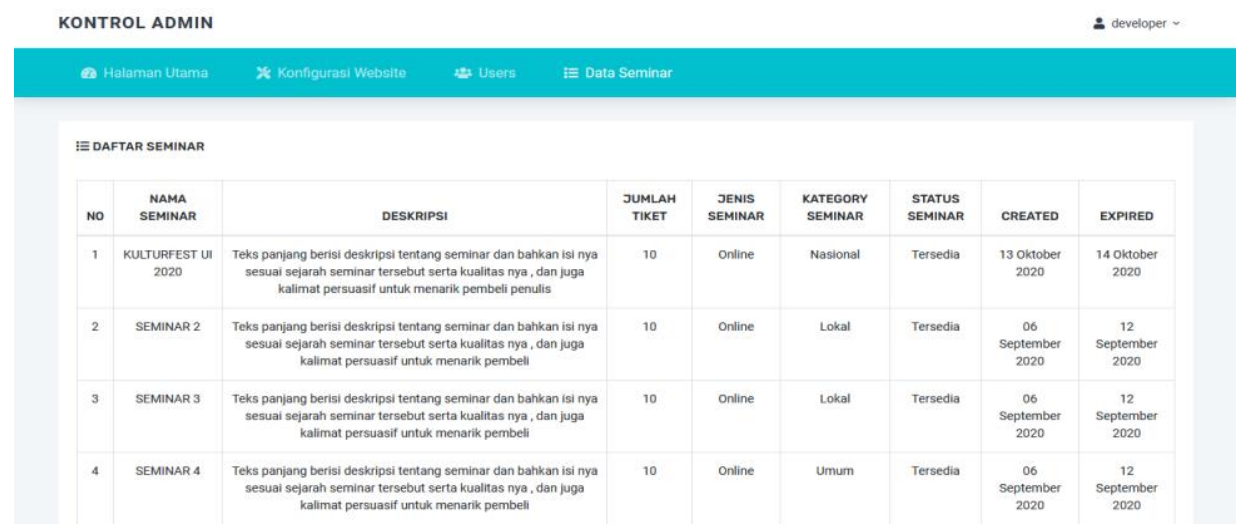

Gambar 7. Tampilan Daftar Seminar

\section{f. Halaman Dashboard Admin}

Halaman dashboard administrator adalah halaman awal yang tertampil ketika administrator melakukan login ke dalam sistem. Pada dashboard administrator, terdapat menu Peserta Seminar, Daftar Seminar, Pembayaran, Laporan Data Seminar. Tampilan halaman dashboard administrator dapat dilihat pada Gambar 8.

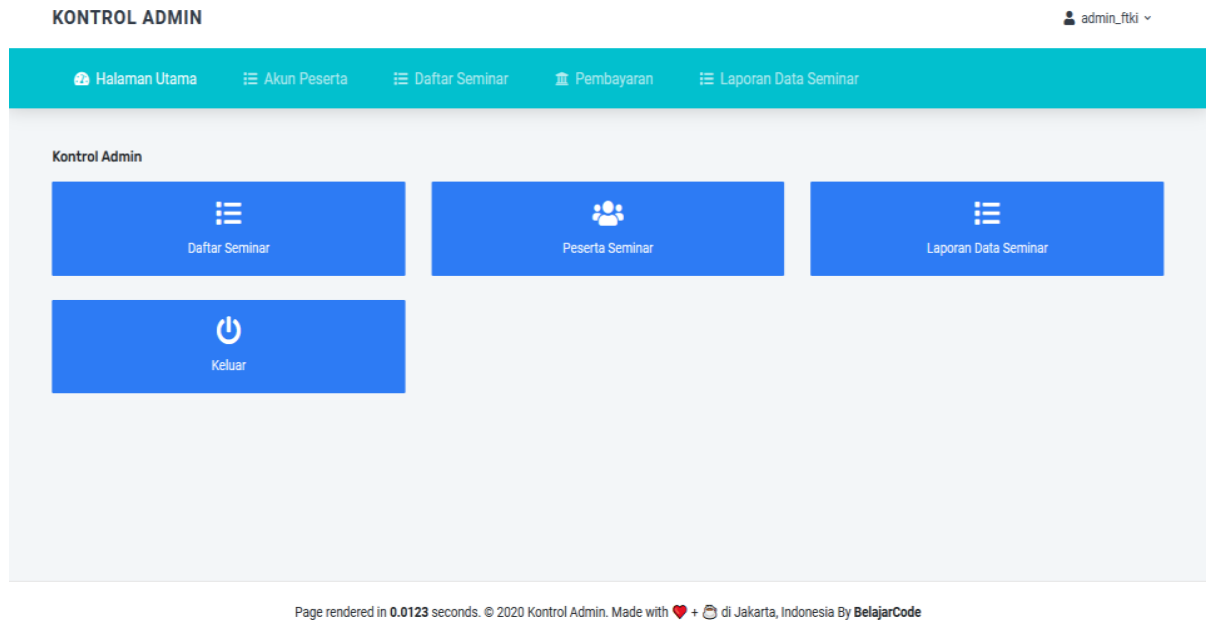

Gambar 8. Tampilan Dashboard Admin

\section{g. Halaman Menu Daftar Seminar}

Halaman Menu Daftar Seminar adalah menu yang di gunakan admin untuk melihat, menambah, menghapus, dan mengedit daftar seminar. Tampilan halaman menu daftar seminar dapat dilihat pada Gambar 9. 
JURNAL MEDIA INFORMATIKA BUDIDARMA

Volume 5, Nomor 1, Januari 2021, Page 129-137

ISSN 2614-5278 (media cetak), ISSN 2548-8368 (media online)

Available Online at https://ejurnal.stmik-budidarma.ac.id/index.php/mib

DOI 10.30865/mib.v5i1.2578

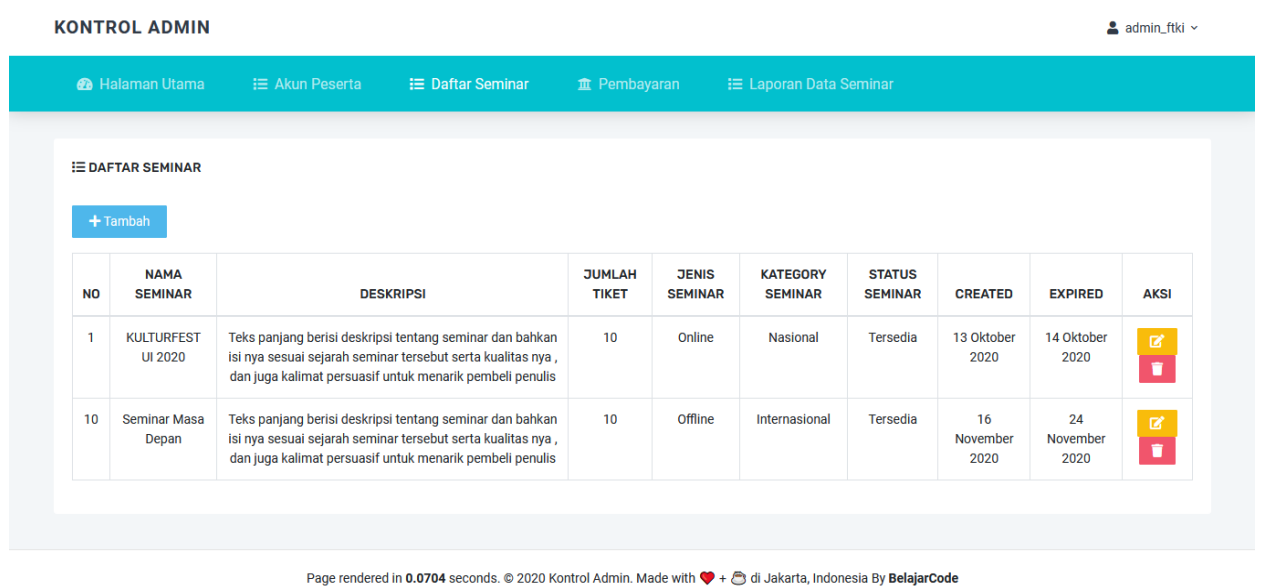

Gambar 9. Tampilan Menu Daftar Seminar

\section{h. Halaman Menu Peserta Seminar}

Halaman Menu Peserta Seminar adalah halaman yang menampilkan nama, npm, no.hp, email, instansi, fakultas, dan jurusan peserta seminar, admin juga dapat menghapus dan mengedit peserta seminar. Tampilan halaman menu peserta seminar dapat dilihat pada Gambar 10.

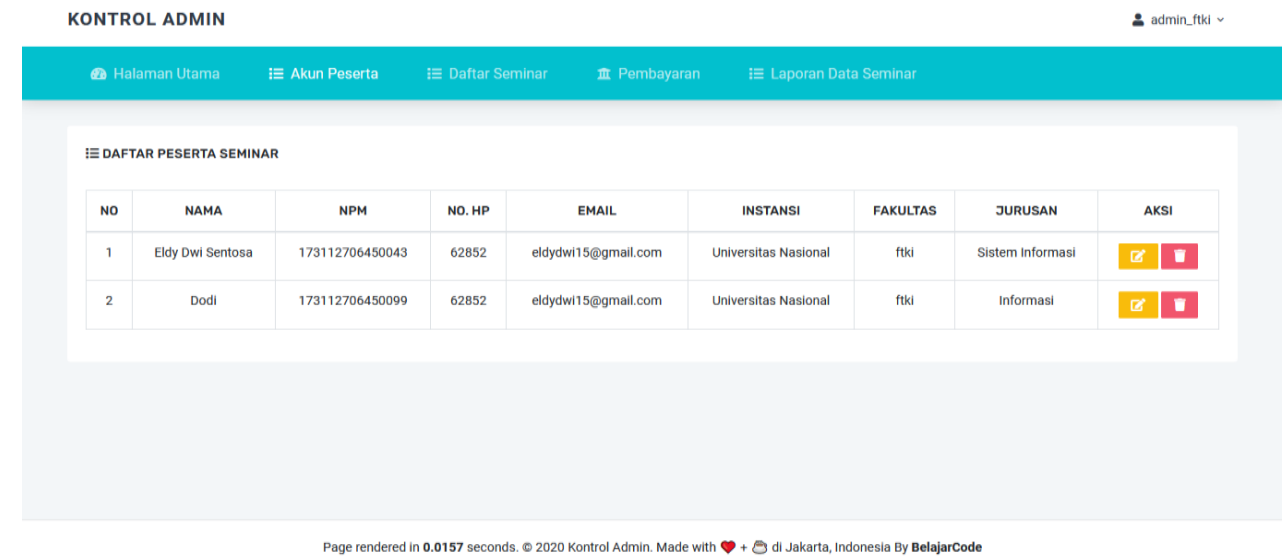

Gambar 10. Tampilan Menu Peserta Seminar

\section{i. Halaman History Pembayaran Seminar}

Halaman History Pembayaran Seminar adalah menampilkan riwayat pembayaran seminar peserta yang sudah membayar, belum membayar dan gagal melakukan pembayaran tiket seminar. Tampilan halaman History Pembayaran Seminar dapat dilihat pada Gambar 11.

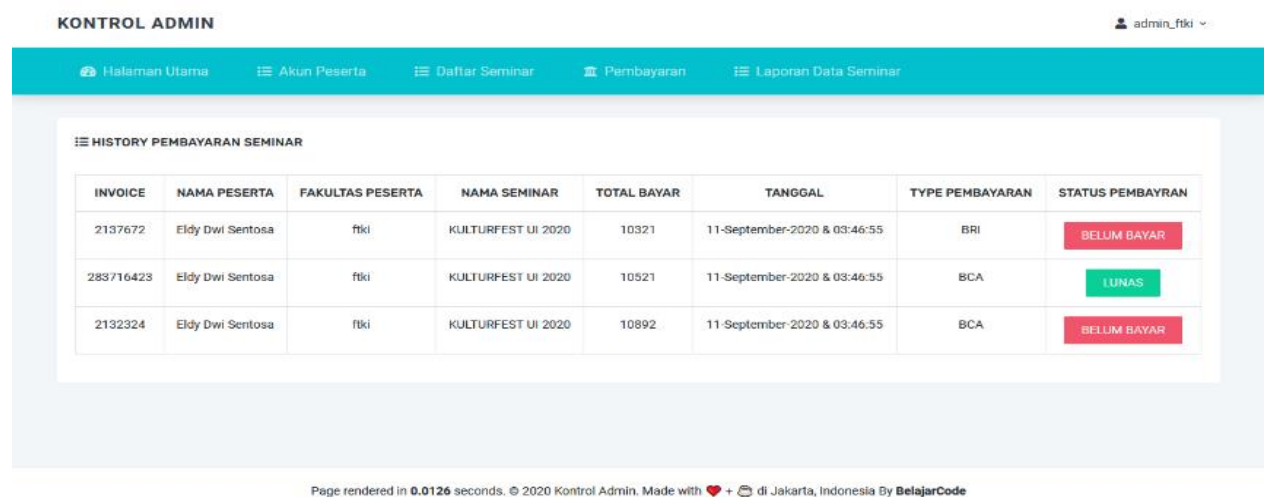

Gambar 11. Tampilan History Pembayaran Seminar

\section{j. Halaman Laporan Peserta Seminar}

Halaman Laporan Peserta Seminar adalah menampilkan peserta seminar yang sudah melakukkan pembayaran tiket seminar, dihalaman ini admin juga dapat merekap data dengan cara meng-export ke format excel. Tampilan halaman Laporan Peserta Seminar dapat dilihat pada Gambar 12. 


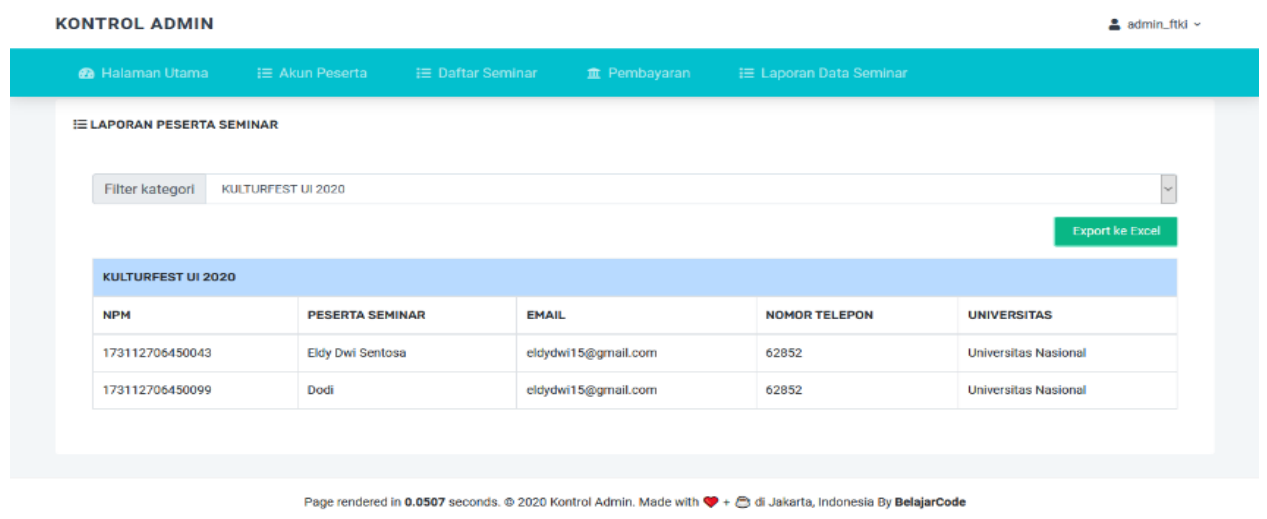

Gambar 12. Tampilan Laporan Peserta Seminar

\section{k. Halaman Daftar Rekening}

Halaman Pembayaran Daftar Rekening adalah menampilkan Nama Bank Fakultas, Account, Jenis Bank, Kode OTP (untuk jenis GOPAY Dan OVO), PIN (untuk jenis OVO), Saldo (Saldo Rekening), admin juga dapat menambahkan, menghapus dan mengedit rekening yang akan di gunakan. Tampilan halaman Daftar Rekening dapat dilihat pada Gambar 13.

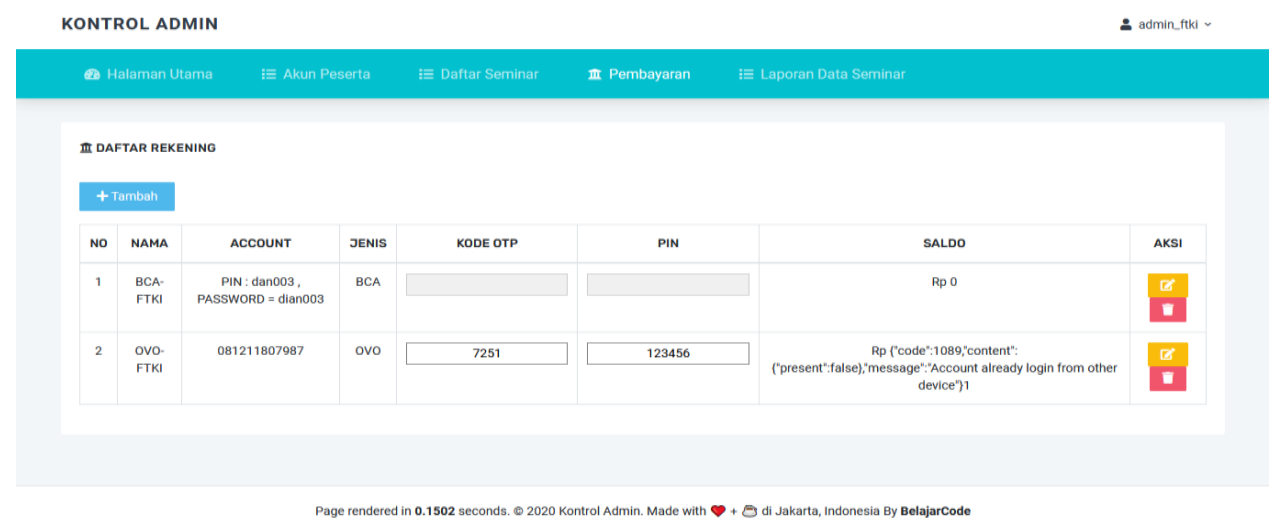

Gambar 13. Tampilan Daftar Rekening

\section{Halaman Verifikasi Pembayaran}

Halaman Verifikasi Pembayaran adalah halaman dimana menampilkan semua proses verifikasi pembayaran peserta seminar mulai dari yang sudah membayar seminar, belum membayar, serta yang sudah melakukan pembayaran. Tampilan halaman verifikasi pembayaran dapat dilihat pada Gambar 14.

\section{$\underset{\substack{2 \\ 4 \Rightarrow \text { BELLMMEMBAYAR }}}{4 \text { BELMMEMAAARR }}$}

Gambar 14. Tampilan Verifikasi Pembayaran

\section{m. Pengaturan Proses Verifikasi Pembayaran}

Jadwal proses Verifikasi pembayaran diatur cron job yang ada pada sistem operasi linux ubuntu. Cron adalah modul linux yang digunakan oleh pengguna untuk menjalankan perintah pada waktu yang telah di tentukan disistem operasi [17]. Seperti pada gambar 15 tampilan dari konfigurasi jadwal proses verifikasi pembayaran.

\section{Current Cron Jobs}

\begin{tabular}{|c|c|c|c|c|c|c|c|}
\hline Minute & Hour & Day & Month & Weekday & Command & Actions & \\
\hline$* / 5$ & * & * & * & * & wget --spider http://seminarku.my. id/Pembayaran/bca & Edit & 首 Delete \\
\hline$* / 5$ & * & * & * & * & wget --spider http://seminarku.my.id/Pembayaran/ovo & Edit & 而 Delete \\
\hline$* / 5$ & * & * & * & * & wget --spider http://seminarku.my.id/Pembayaran/gopay & Edit & 而 Delete \\
\hline
\end{tabular}

Gambar 15. Tampilan Konfigurasi Proses Verifikasi Pembayaran 
JURNAL MEDIA INFORMATIKA BUDIDARMA

Volume 5, Nomor 1, Januari 2021, Page 129-137

ISSN 2614-5278 (media cetak), ISSN 2548-8368 (media online)

Available Online at https://ejurnal.stmik-budidarma.ac.id/index.php/mib DOI 10.30865/mib.v5i1.2578

\subsection{Pengujian Sistem}

Hasil Pengujian Menggunakan Blackbox

Tabel 1. Tabel fitur Developer

\begin{tabular}{|c|c|c|c|c|}
\hline No & Input & Fungsi & Output & Hasil \\
\hline 1 & $\begin{array}{c}\text { Developer mendaftarkan } \\
\text { akun Admin } \\
\text { (Penyelenggara Seminar) } \\
\text { penyelenggara seminar }\end{array}$ & $\begin{array}{l}\text { Membuat akun Admin } \\
\text { (Penyelenggara Seminar) }\end{array}$ & $\begin{array}{c}\text { Admin dapat login } \\
\text { dengan akun yang } \\
\text { dibuatkan } \\
\text { Developer }\end{array}$ & Sesuai \\
\hline 2 & $\begin{array}{l}\text { Developer melihat daftar } \\
\text { User (Peserta Seminar) }\end{array}$ & $\begin{array}{l}\text { Hanya melihat daftar User } \\
\text { (Peserta Seminar }\end{array}$ & $\begin{array}{c}\text { Menampilkan daftar } \\
\text { User (Peserta } \\
\text { Seminar) }\end{array}$ & Sesuai \\
\hline 3 & $\begin{array}{c}\text { Developer melihat daftar } \\
\text { Admin (Penyelenggara } \\
\text { Seminar) }\end{array}$ & $\begin{array}{c}\text { Melihat daftar akun } \\
\text { Admin (Penyelenggara } \\
\text { Seminar) }\end{array}$ & $\begin{array}{c}\text { Menampilkan daftar } \\
\text { akun Admin } \\
\text { (Penyelenggara } \\
\text { Seminar). }\end{array}$ & Sesuai \\
\hline 4 & $\begin{array}{l}\text { Developer mengedit Admin } \\
\text { (Penyelenggara Seminar) }\end{array}$ & $\begin{array}{c}\text { Mengubah data dari } \\
\text { admin (Penyelenggara } \\
\text { Seminar) }\end{array}$ & $\begin{array}{l}\text { Menampilkan } \\
\text { halaman untuk } \\
\text { mengubah data } \\
\text { admin }\end{array}$ & Sesuai \\
\hline 5 & $\begin{array}{l}\text { Developer menghapus data } \\
\text { admin }\end{array}$ & Menghapus data admin & Data admin dihapus & Sesuai \\
\hline 6 & Developer logout & $\begin{array}{l}\text { Keluar dari meny } \\
\text { Developer }\end{array}$ & $\begin{array}{l}\text { Menampilkan } \\
\text { halaman Login }\end{array}$ & Sesuai \\
\hline
\end{tabular}

Tabel 2. Testing dan Uji Coba Admin

\begin{tabular}{|c|c|c|c|c|}
\hline No & Input & Fungsi & Output & Hasil \\
\hline 1 & $\begin{array}{c}\text { Admin mendaftarkan } \\
\text { acara seminar }\end{array}$ & $\begin{array}{c}\text { Membuat data acara yang } \\
\text { akan di selenggarakan. }\end{array}$ & $\begin{array}{l}\text { Acara bisa dipilih peserta pada } \\
\text { halaman utama dan panitia bisa } \\
\text { mengelola acara tersebut }\end{array}$ & Sesuai \\
\hline 2 & $\begin{array}{c}\text { Admin Login dengan } \\
\text { akun yang sudah } \\
\text { dibuatkan developer }\end{array}$ & $\begin{array}{l}\text { Mengelola acara yang di } \\
\text { selenggarakan }\end{array}$ & $\begin{array}{l}\text { Menampilkan dihalaman } \\
\text { peserta }\end{array}$ & Sesuai \\
\hline 3 & $\begin{array}{l}\text { Admin mengisi } \\
\text { keterangan acara }\end{array}$ & $\begin{array}{l}\text { Menampilkan deskripsi } \\
\text { acara }\end{array}$ & $\begin{array}{l}\text { Menampilkan halaman } \\
\text { deskripsi acara }\end{array}$ & Sesuai \\
\hline 4 & $\begin{array}{l}\text { Admin mengedit data } \\
\text { peserta }\end{array}$ & Mengubah data dari peserta & $\begin{array}{l}\text { Menampilkan halaman untuk } \\
\text { mengubah data acara }\end{array}$ & Sesuai \\
\hline 5 & $\begin{array}{l}\text { Admin delete data } \\
\text { peserta }\end{array}$ & Menghapus data peserta & Data peserta dihapus & Sesuai \\
\hline 6 & $\begin{array}{l}\text { Admin mengexport } \\
\text { data peserta yang } \\
\text { sudah membayar ke } \\
\text { dalam dokumen } \\
\text { Excel }\end{array}$ & $\begin{array}{l}\text { Membuat data peserta } \\
\text { menjadi file Excel }\end{array}$ & Data_user.xls & Sesuai \\
\hline 7 & $\begin{array}{l}\text { Admin melihat } \\
\text { history pembayaran } \\
\text { peserta }\end{array}$ & $\begin{array}{c}\text { Melihat status pembayaran } \\
\text { peserta dari belum } \\
\text { membayar sampai yang } \\
\text { sudah membayar }\end{array}$ & $\begin{array}{c}\text { Menampilkan status } \\
\text { pembayaran peserta dari belum } \\
\text { membayar sampai yang sudah } \\
\text { membayar }\end{array}$ & Sesuai \\
\hline 8 & Admin logout & Keluar dari Kontrol Admin & Menampilkan halaman Login & Sesuai \\
\hline
\end{tabular}

\section{KESIMPULAN}

Berdasarkan perancangan dan pembuatan pembayaran otomatis tiket seminar dengan Algoritma Crawling dapat disimpulkan bahwa Sistem Keamanan di website pemesanan tiket seminar untuk meningkatkan keamanan dan kenyamanan mahasiswa dalam melakukan transaksi online, Mempersingkat waktu yang diperlukan untuk melakukan proses pembayaran seminar yang rekapitulasi daftar peserta yang sudah membayar untuk mengikuti seminar. Hasil pengujian sistem ini menggunakan blackbox juga berjalan dengan baik.

\section{REFERENCES}


JURNAL MEDIA INFORMATIKA BUDIDARMA

Volume 5, Nomor 1, Januari 2021, Page 129-137

ISSN 2614-5278 (media cetak), ISSN 2548-8368 (media online)

Available Online at https://ejurnal.stmik-budidarma.ac.id/index.php/mib

DOI 10.30865/mib.v5i1.2578

[1] M. M. Belalawe, "Tinjauan Keamanan Sistem Transaksi dan Pembayaran pada E-Commerce Studi Kasus Toko Online," Tinj. Keamanan Sist. Transaksi dan Pembayaran pada E-Commerce Stud. Kasus Toko Online, vol. 2013, no. Sentika, pp. 1-6, 2013.

[2] P. Studi, T. Informatika, F. Teknik, and U. P. Bandung, "PERANCANGAN SISTEM PEMBAYARAN NON - TUNA TRANPORTASI PUBLIK DARAT MODA JALAN RAYA ( Studi Kasus: Angkutan Kota dan Bus Kota ) ‘ PERANCANGAN SISTEM PEMBAYARAN NON - TUNAI TRANPORTASI PUBLIK DARAT MODA JALAN RAYA," 2018

[3] H. Santono, "Implementasi Sistem Informasi Pembayaran SPP Berbasis Web, Barcode, dan SMS Gateway," Pros. Semin Nas. Teknol. Inf. dan Komun., vol. 2, no. 1, pp. 255-260, 2019.

[4] dan H. Erna Astriyani, Meri Mayang Sari, "Perancangan Sistem Informasi Pembayaran SPP Berbasis Web Menggunakan Notifikasi SMS Gateway," vol. 6, pp. 106-116, 2020.

[5] F. MAGALINE, B. N. MAHAMUDU, and E. HO, "Sistem Informasi « sistem informasi," Sist. Inf., vol. 8, no. Kommit, p. 2019, 2019, [Online]. Available: https://d1wqtxts1xzle7.cloudfront.net/40023643/Bab_01Data_dan_Informasi.pdf?1447602912=\&response-content-

disposition=inline \%3B+filename\%3DBab_01_Data_dan_Informasi.pdf $\&$ Expires $=1605595367 \&$ Signature $=$ NB261 yhn EnDNU5SxKhyNp--V4DBSM7bABubBEONhCBHfvTuyJXC8 0UkH.

[6] A. H. Arribathi, P. Studi, S. Informasi, U. Raharja, P. S. Tekhnik, and I. U. Raharja, "Perancangan aplikasi," vol. 5, no. 2, pp. 156-164, 2019.

[7] M. Agarina and A. S. Karim, "Rancang Bangun Sistem Informasi Kegiatan Seminar Nasional Berbasis Web Pada Institut Informatics Dan Bisnis Darmajaya," Explor. J. Sist. Inf. dan Telemat., vol. 10, no. 1, 2019, doi: 10.36448/jsit.v10i1.1215.

[8] Mustakim, Guntoro, U. Khaira, W. Kalengkongan, and Hidayat, "Perancangan Sistem Informasi Pendaftaran Seminar Mahasiswa Pascasarjana Institut Pertanian Bogor," J. Ilm. Rekayasa dan Manaj. Sist. Inf., vol. 1, no. 2, pp. 6-14, 2015.

[9] S. Dian, H. Permana, and R. Setiawan, "Perancangan Dan Pembangunan Sistem Informasi Portal Seminar Dan Jurnal Berbasis Web Menggunakan Framework Code Igniter,” Semin. Nas. Teknol. Inf. dan Multimed. 2017, pp. 175-180, 2017.

[10] D. Dermawan, D. S. D. Putra, and L. W. Kusuma, "Aplikasi Pendaftaran Seminar Menggunakan Metode Mvc Berbasis Website Menggunakan Framework Codeigniter 3.1.10," J. Algor, vol. 1, no. 2, pp. 23-29, 2020

[11] F. Sabirin, D. Sulistiyarini, and Z. Zulkarnain, "Pengembangan Sistem Informasi Seminar dan Skripsi Mahasiswa," Edumatic J. Pendidik. Inform., vol. 4, no. 1, pp. 73-82, 2020, doi: 10.29408/edumatic.v4i1.2048.

[12] D. A. Adi Nugroho and H. Supriyono, "Sistem Informasi Pendaftaran Seminar Dengan Tiket Berbasis Qr Code," Emit. J. Tek. Elektro, vol. 19, no. 1, pp. 36-40, 2019, doi: 10.23917/emitor.v19i1.7439.

[13] R. Hanifah and I. S. Nurhasanah, "Implementasi Web Crawling Untuk Mengumpulkan Web Crawling Implementation for Collecting," J. Teknol. Inf. dan Ilmu Komput., vol. 5, no. 5, pp. 531-536, 2018, doi: 10.25126/jtiik20185842.

[14] A. Stanley, "Analisis Penerapan Algoritma DFS dan BFS pada Web Crawling / Spider," 2019.

[15] E. Zuliarso, "Aplikasi Web crawler Berdasarkan Breadth First Search dan Back-Link," Fak. Teknol. Informasi, Univ. Stikubank Semarang, vol. XV, no. 1, pp. 52-56, 2010.

[16] A. Lasmedi and I. Permadi, "Rancang Bangun Sistem Infomasi Laboratorium (SILAB) Berbasis WEB Di Teknik Informatika UNSOED," Pros. SNST Fak. Tek., vol. 1, no. 1, pp. 26-32, 2013.

[17] J. Moedjahedy, "Implementasi Cron Job Linux Sebagai Bel Pergantian Kelas Otomatis Di Universitas Klabat," CogITo Smart J., vol. 4, no. 1, p. 1, 2018, doi: 10.31154/cogito.v4i1.97.1-10. 